\title{
OPERATIONAL BUDGETING IN HOSPITALITY
}

\author{
Nikica Radović, Tijana Radojević \\ Faculty of Tourism and Hospitality Management, Singidunum University, Belgrade, Serbia
}

\begin{abstract}
:
Successful business enterprises are based on reliable and proper financial reporting. Financial reporting is the basis in forming valuable components that make up the elements of the budget. In hospitality industry, budget appears as a set business plan, but also as an instrument of control efficiency. Through the operating budget, management of a hotel is able to compare planned and actual values in business in a financial year and this continuously examines the results of its operations. The aim of this paper is to highlight the important role of operational budgeting in the complex system of
\end{abstract} business enterprises in the hospitality industry.

\section{Key words:}

budgeting,

planning,

hotel industry

\section{INTRODUCTION}

To be successful in business, every company needs to create a business plan that forms the basis of management decisions. Based on the business plan, company defines the objectives of the business, looks at the risks and uncertainties and develops business activities that lead to the realization of the set goals. A very important part of the business plan relates to the financial plan for a certain period of operation, which is called a budget. Budget is one of the key management decisions, while at the same time predictive techniques, and also instrument of planning and control [1].

In the process of budgeting, management defines the holders of the budgeting process, method of preparation, alignment, review and approval of the budget [2]. The business activities of small businesses, over the formation of the budget process, are not defined, they are spontaneous. While in the business of larger systems, it is desirable to define the steps and observe them for more effective budgeting.

When creating a budget, it is necessary to comply with the defined procedures for this activity, based on the choice of the method according to which the budget is created. Three methods of creating the budget are well-known[1].

a) from top to bottom - top managers make up the budgets of all organizational parts and pass them to managers sector.

b) bottom-up - the first version of the business plan make managers by sector, and then send them to the correction, alignment and acceptance by top management.

c) Zero based budgeting - The starting point is the idea that the budget for the next period of business activity is equal to zero, and the management has an obligation to define the purpose for the use of funds. It is started with the division of responsibilities between the managers, each in its sector, have to identify and justify the proposal of the business plan. In this way, it is necessary to analyze the costs and benefits of all of the activities and decide which they think should be achieved in the next period. Method Zero based budgeting is typically used for marketing, research and development sector, the sector of human resources, etc.

According to [3], advantages of Zero Based Budgeting include: rational allocation of resources according to the needs of the sector, defining the optimal allocation of resources, the efficient discovery of artificially increased budget, increasing coordination, communication and motivation within the organization. Also this method has disadvantages and they relate to the lack of flexibility because the budgeting process requires precisely defined period, and management must be trained to know to carry out activities at all levels.

\section{OPERATIONAL BUDGETING IN HOSPITALITY}

The hotel business is characterized by complex business processes, given the nature of many activities that take place in daily operations in several departments (sectors). At the same time, a significant impact on the operations of the hotel company is reflected in the changing internal and external developments in the tourism market. In connection with the foregoing facts, it is confirmed that for hotel company is very important to have created a business plan. Budget of a hotel company is a financial business plan for the upcoming financial year.

When hotel company prepares the budget for upcoming year, they usually used method of bottom-up.

According to this method, managers of department within the hotel company, at the request of the General Manager, are obliged to make their department budgets which then will be integrated into a general budget of a company. Then the general budget is given to the control of the General Manager who than forwarded for approval and acceptance of the Supervisory Board or the owner. Annual adopted and approved budget does not change and is the final business plan for the new fiscal year [4]. The aim of the budgeting in hotel company is defining values of income and expenditures for each organizational unit of business, in order to project the results pursued.

In hospitality industry, operating and capital budget are usually created. Operating budget by sector includes planned revenues and expenditures. Capital budget includes activities planned to invest in a hotel company. Investments that are often perceive through these financial plan are: investments that are related to regular maintenance of equipment, purchase inventory, urgent investments in the event of a failure in the course of providing services to guests, etc. Operating and capital budgets are interrelated and are indispensable for the needs of a successful business. The information contained in the operating budget indicate financial opportunities for investment and information from capital budget presented the period of return on investment.

Acoording to operating and capital budgets, in hospitality is necessary to prepare the financial budget. The financial budget is based on short-term business plans, ie. at the level of a financial 
year, in accordance with the market situation and competitive position and is the most common form of business planning in the hotel business. Procedure of preparation is based on a detailed, monthly, defining financial value for each organizational unit in hotel company. Therefore, we have an insight into the planned monthly business of every hotel departments (sectors), and enable continuous control business in departments (sectors) within the hotel company. In hospitality budgets are created by departments (sectors): the budget of accommodation sector, the budget of food and beverage sector, the budget of administration, the budget of current and investment maintenance, the budget of marketing sector and the budget of other services that hotel provides guests (telephone services, laundry services, spa \& wellness center) [1].

The process of creating a budget based on a specific order of collecting information from the previous period with the necessary understanding of market trends and their impact on the operations of the analyzed companies. Data collection include individual sector spending, price trends, along with the projection of the necessary corrections for the future. In the analysis, also are included data on business competition (price, capacity) and business climate at the level of business sectors. Bearing in mind that in hotel business operates several sectors, it is necessary to define activities and tasks for individual sectors, and then integrated them into a common budget.

The basis for creating the operating budget represents the budget of room sector, bearing in mind that the provision of accommodation is the primary activity of the hotel company, for whose formation is responsible the manager of this sector. In the process of creation this budget, the basic unit is the number of nights, and the necessary data that are included in the analysis are the data on the number of nights for the previous financial year, pre-agreed number of guests for the next period, the activities of competitors, changes in macroeconomic indicators, the events at the destination level, economic and political developments in the region, and the like. Food and beverage sector, which budget creates manager in charge of this sector, in addition to room sector is one of the carriers of hotel business. For the purposes of this budget we analyzed the data pertaining to the number of guests that spend night in the hotel and the number of guests who had daily activities in the hotel (meetings, seminars, presentations, banquets, weddings, etc.). When implementing the service delivery of room sectors and food and beverage sector, we have the cost of materials, so it is important to create a budget of material costs in order to define the planning necessary supplies and resources indispensable to conduct regular business processes in the following period. The most effective way is when defining these costs it should follow standards when creating menus and dishes that will store and serve. Maintenance costs of linen, towels and tablecloths, hygiene products in the rooms and other rooms of accommodation facilities, supplies equipment and accessories in the rooms, the write-off of bedding, towels and tablecloths, TV subscription, as well as the costs of postal services are among the direct costs of operating budget in hotel company, which is formed on a monthly basis or as needed.

\section{OPERATIVNO BUDŽETIRANJE U HOTELIJERSTVU}

Nikica Radović ${ }^{\text {, Tijana Radojević }}{ }^{2}$

${ }^{1}$ Fakultet za turistički i hotelijerski menadžment, Univerzitet Singidunum, Danijelova 32, Beograd, Srbija, nradovic@singidunum.ac.rs ${ }^{2}$ Fakultet za turistički i hotelijerski menadžment, Univerzitet Singidunum, Danijelova 32, Beograd, Srbija, tradojevic@singidunum.ac.rs

\section{Apstrakt:}

Uspešno poslovanje preduzeća zasniva se na pouzdanom i ispravnom finansijskom izveštavanju. Ono predstavlja osnov prilikom formiranja vrednosnih komponenti koje čine elemente budžeta. U poslovanju hotelskog preduzeća budžet se pojavljuje kao zadati poslovni plan, ali i kao instrument kontrole efikasnosti poslovanja. Putem operativnog budžeta menadžment hotelskog preduzeća je u mogućnosti da na nivou poslovne godine poredi planirane i ostvarene vrednosti u poslovanju preduzeća i na taj način u kontinuitetu sagledava rezultate svog poslovanja. Cilj ovog rada je da ukažemo na važnu ulogu koju operativno budžetiranje ima u složenom sistemu poslovanja preduzeća u hotelskoj industriji.
In a series of individual budgets is necessary to create the marketing budget, which should include the promotion of the business plan of hotel company - trade shows, TV appearances, advertising of printed materials and the like. At the same time, we should pay attention to the administration budget of a hotel company which include planned items of salaries, fees and representation.

If the hotel company has more organizational units ie. more places where it provides its services, it is necessary that each organizational unit individually make their budgets by sector.

\section{CONCLUSION}

Budgeting is a quantitative definition of the elements of a business plan as an integral part of organizational business planning, as one of the four elements of strategic management. At the beginning of the budget development it is necessary to do a detailed analysis of business operations in order to detect defects and hazards in operations, with a view to making a decision on which to overcome and improve business processes. In this way, through sector budget at the level of organizational units is enabled continuous insight into complex business of a hotel company. Actual performance results that are achieved may be a monthly compared with target values within sectors, within organizational units, as well as on the whole level of the hotel company.

Monthly comparison and analysis enables the flexible and precise response to variations in the business. In this way, the operating budget is controlled by the hotel management company ie. in addition to its planning function it has a controlling role in business. After the analysis of planned and actual values in business of hotel company and defining deviations, management brings a certain strategic decisions relating to the assessment, for instance, whether it is necessary to revise the budget for the coming period, whether due to the state budget costs must examine and rearrange business activities or everything is in satisfactory, planned level of values and it is not necessary to download any activities.

\section{REFERENCES}

[1] M. Stanišić, N.Radović, „Operativno budžetiranje i kontrola sa aspekta poslovanja hotelskog preduzeća“, Referat saopšten na Međunarodnom naučnom skupu SM2011, Zbornik radova ISBN 978-867233286-5, Ekonomski fakultet, Subotica, 2011.

[2] N. Stevanović, V. Milićević, D. Malinić, Upravljačko računovodstvo, Univerzitet u Beogradu, Ekonomski fakultet, Beograd, 2007.

[3] J. Acosta, "Zero-Based Budgeting in the Hospitality Industry", (2006) Hotel Online - Special Report (access: 24/07/2008.) [available on site http://www.hotel-online.com/]

[4] R. Lukić, D. Nikolić, „Budžetiranje u hotelskom poslovanju“, HOTELlink - Časopis za hotelijerstvo, restoraterstvo i gastronomiju (9-10), Beograd, Visoka hotelijerska škola, 2007, p. 707

\section{Ključne reči:}

budžetiranje,

planiranje,

hotelska industrija. 